\title{
Genetic variability in peas (Pisum sativum L.) from Turkey asssessed with molecular and morphological markers
}

Fatih Hanci

Erciyes University Kayseri, Turkey

\begin{abstract}
The aim of this study was to identify the molecular and morphological characteristics of Turkish pea accessions (Pisum sativum L.). The genetic diversity among 130 Turkish landraces and 2 commercial varieties in a total of 132 pea accessions was assessed with 14 simple sequence repeat (SSR) markers. Forty-eight (48) polymorphic alleles were identified using 14 SSR markers. The pairwise Dice coefficients of similarity between accessions ranged from 0.091 to 0.960 . The polymorphism information content (PIC) value ranged from 0.585 to 0.861 . Overall, 50 morphological traits were evaluated. Cluster analysis was carried out on a matrix of Euclidean distances. The accessions were divided into three main groups. Principal component analysis (PCA) was used to identify the weight of each morphological characteristic. According to the results, the highest eigenvalue was observed in PC-I (13.88) followed by PC-II (11.42), and PC-III (7.32). The first fifteen PCs with eigenvalues $>1$ explained $74.08 \%$ of the variability. The results showed that the molecular markers were useful and polymorphic, sufficient to allocate all the evaluated accessions. This research has provided significant insights into the genetic variability of Turkish pea accessions.
\end{abstract}

Key words: breeding, cluster analysis, diversity, pea, polymorphism

\section{INTRODUCTION}

Having more than 650 genera and 18,000 species, the legumes are the third uppermost family of flowering plants (Lewis et al., 2005). Globally, the pea (Pisum sativum L.) is the second most important pulse crop after the common bean (Phaseolus vulgaris L.) in terms of grain yield and sixth in terms of cultivation area (Kumari et al., 2013).

It is assumed that the "Fertile Crescent" through Turkey, Iraq, Lebanon, Israel, and Syria is the centre of pea genetic diversification (Smýkal et al., 2013). Morphological characteristics and agronomical traits have been used by several studies conducted on the genetic diversity in the genus Pisum (Yirga et al., 2013; Gixhari et al., 2014; Ouafi et al., 2016). A few techniques are effective for investigating morphological variation in a genetic resource. The principal component analysis (PCA), as a multivariate statistical technique, can convert numerous contingent correlated factors into a few factors that are termed principal components (Ziegel, 2006).

Morphological markers are influenced by environmental factors to a greater extent in comparison with biochemical and molecular markers. Molecular markers serve as a tool to overcome the deficiencies of morphological markers (Rao, 2004), because molecular markers are not influenced by environmental factors (Tatikonda et al., 2009). For high polymorphisms, co-dominance, 
and locus specificity widely distributed throughout the genome, simple sequence repeat (SSR) markers have increasingly become the favourite marker set for genetic work (Cuevas and Prom, 2013; Izzah et al., 2013). As with many other species, these markers have previously been preferred to define genetic variation of pea accessions (Tar'an et al., 2005; Nasiri et al., 2009; Nisar et al., 2017).

Despite their high economic value, an important part of Turkish pea accessions has not been described genetically. The aim of this research was to characterize the genetic variation of this germplasm by means of morphological and molecular markers, and to identify/examine the extensive implications of the research for prospective breeding and gene-bank conservation programmes.

\section{MATERIAL AND METHODS}

\section{Plant materials}

The experiments were carried out at the Atatürk Central Horticultural Research Institute, Yalova, Turkey. The 130 pea accessions, which originated from different regions of Turkey, had been kindly obtained from Plant Gene Banks [Western Regional Plant Introduction Station, USDA, Pullman, (USA); John Innes Centre (UK); Gene Bank of the Aegean Agricultural Research Institute (TR)]. The cultivars Kaysee and Serge were used as the control. The seeds were planted in the field at the end of November 2015 and November 2016. The morphological data were collected from two one-year experiments. Seeds of each accession were sowed in $1.0 \times 1.6 \mathrm{~m}$ plots. At least sixty plants were grown in each plot in a Randomized Complete Block Design with three replications. Routine maintenance procedures such as irrigation, weeding, disease and pest control were performed throughout the growing season.

\section{Molecular characterization}

Total genomic DNA was isolated according to Hanci and Gökçe (2016a). For the DNA isolation studies, parts of fresh young leaves were collected from 20-day-old pea $(P$. sativum L.) seedlings. For the extraction, a bulk sample was prepared from six plants for each accession. A MachereyNagel NucleoSpin ${ }^{\circledR}$ Plant II kit (Macherey-Nagel $\mathrm{GmbH}$ and Co. KG., Düren, Germany) was used for isolation. The steps of the work were carried out according to the manufacturer's instructions.

The SSR assay was carried out using fourteen primers (Tab. 1). The high-quality SSR markers with a relatively high polymorphic information content were selected based on the data provided by previous studies (Loridon et al., 2005). The PCR reaction volume was $25 \mu \mathrm{L}$, consisting of $0.6 \mathrm{mM}$ reverse and forward primers, $200 \mu \mathrm{M}$ deoxyribonucleotide triphosphates, 20-25 ng genomic DNA, $1 \mathrm{X}$ Taq buffer, $2 \mathrm{mM} \mathrm{MgCl} 2,1 \mathrm{U}$ Taq-DNA polymerase (Fermentas, Pittsburgh, PA, USA) (Kumari et al., 2013). A typical PCR procedure was as follows: initial denaturation for $3 \mathrm{~min}$. at $94^{\circ} \mathrm{C}$, followed by 40 cycles of $94^{\circ} \mathrm{C}$, $51^{\circ} \mathrm{C}$ or $61^{\circ} \mathrm{C}$ for $30 \mathrm{~s}, 1 \mathrm{~min}$. at $72^{\circ} \mathrm{C}$, and the final extension for $10 \mathrm{~min}$. at $72^{\circ} \mathrm{C}$ before cooling at $4^{\circ} \mathrm{C}$. The amplified fragments were separated by electrophoresis on a $3 \%$ agarose gel containing ethidium bromide.

For data analysis, the amplified bands generated by SSR-PCR amplification were scored based on the presence (1) or absence (0) of bands for each primer (Nisar et al., 2017). Cluster analysis was performed on the molecular data using the un-weighted pair group method based on arithmetic means (UPGMA) algorithm. The information of each pair primer was deduced using the polymorphic information content (PIC) as described by Hildebrand et al. (1992):

$$
P I C=1-\sum_{i=1}^{n} p_{i}^{2}-2 \sum_{\mathrm{i}=1}^{\mathrm{n}-1} \sum_{j=i+1}^{n} p_{i}^{2} p_{j}^{2}
$$

where $p_{i}$ and $p_{j}$ are the population frequency of the ith and jth allele. The similarity matrix was formed using Dice's coefficient. XLSTAT software (Garcia-Vallve et al., 1999) was used for generating the similarity matrices and UPGMA clustering.

\section{Morphological characterization}

Data on different agronomic characteristics from fifteen individuals randomly chosen from each plot were analysed according to the guide of the International Union for the Protection of New Varieties of Plants (UPOV, 2009) (Tab. 2). The cluster analysis was applied using UPGMA. The Ward method was used to establish a dendrogram from the Euclidean distances of each accession (Gixhari et al., 2014). PCA was used to identify the weight of each characteristic. Numerical scores of 50 traits for the accessions were transformed to standardize the units for PCA. The number of principal components was determined using the minimum eigenvalue (Hanci and Gökçe, 2016b). All the statistical procedures for morphological traits were performed using the SAS Institute Inc. $\mathrm{JMP}^{\circledR}$ and IBM SPSS ${ }^{\circledR}$ Statistics Ver. 221. 
Table 1. Details of the SSR primers (Loridon et al., 2005) and observeded results

\begin{tabular}{|c|c|c|c|c|c|c|}
\hline Marker & Sequence $\left(5^{\prime}-3^{\prime}\right)$ & $\begin{array}{l}\mathrm{Tm}^{*} \\
\left({ }^{\circ} \mathrm{C}\right)\end{array}$ & $\begin{array}{l}\text { Linkage } \\
\text { group }\end{array}$ & $\begin{array}{l}\text { Band size } \\
\text { (bp) }\end{array}$ & $\begin{array}{l}\text { Number } \\
\text { of bands }\end{array}$ & PIC \\
\hline AA122 & $\begin{array}{l}\text { F:GGGTCTGCATAAGTAGAAGCCA } \\
\text { R:AAGGTGTTTCCCCTAGACATCA }\end{array}$ & 61 & IV & $175-225$ & 4 & 0.820 \\
\hline AA205 & $\begin{array}{l}\text { F:TACGCAATCATAGAGTTTGGAA } \\
\text { R:AATCAAGTCAATGAAACAAGCA }\end{array}$ & 51 & II & $175-225$ & 2 & 0.585 \\
\hline AA446 & $\begin{array}{l}\text { F:TTAGCTTGCAGCCCACTC } \\
\text { R:ATCCGACCCATGGATTTA }\end{array}$ & 51 & VII & $650-900$ & 5 & 0.859 \\
\hline AA5 & $\begin{array}{l}\text { F:TGCCAATCCTGAGGTATTAACACC } \\
\text { R:CATTTTTGCAGTTGCAATTTCGT }\end{array}$ & 61 & III & $225-250$ & 3 & 0.755 \\
\hline $\mathrm{AB} 141$ & $\begin{array}{l}\text { F:ATCCCAATACTCCCACCAATGTT } \\
\text { R:AGACTTAGGCTTCCCTTCTACGACTT }\end{array}$ & 61 & III & $175-225$ & 3 & 0.752 \\
\hline $\mathrm{AB} 23$ & $\begin{array}{l}\text { F:TCAGCCTTTATCCTCCGAACTA } \\
\text { R:GAACCCTTGTGCAGAAGCATTA }\end{array}$ & 61 & V & $200-225$ & 3 & 0.777 \\
\hline AC58 & $\begin{array}{l}\text { F:TCCGCAATTTGGTAACACTG } \\
\text { R:CGTCCATTTCTTTTATGCTGAG }\end{array}$ & 61 & V & $200-225$ & 3 & 0.781 \\
\hline AD146 & $\begin{array}{l}\text { F:TGCTCAAGTCAATATATGAAGA } \\
\text { R:CAAGCAAATAGTTGTTTTGTTA }\end{array}$ & 51 & VII & $375-425$ & 6 & 0.861 \\
\hline AD147 & $\begin{array}{l}\text { F:AGCCCAAGTTTCTTCTGAATCC } \\
\text { R:AAATTCGCAGAGCGTTTGTTAC }\end{array}$ & 61 & I & $300-325$ & 3 & 0.786 \\
\hline AA67 & $\begin{array}{l}\text { F:CCCATGTGAAATTCTCTTGAAGA } \\
\text { R:GCATTTCACTTGATGAAATTTCG }\end{array}$ & 51 & I & $330-390$ & 4 & 0.779 \\
\hline AB72 & $\begin{array}{l}\text { F:ATCTCATGTTCAACTTGCAACCTTTA } \\
\text { R:TTCAAAACACGCAAGTTTTCTGA }\end{array}$ & 55 & II & $450-500$ & 4 & 0.799 \\
\hline AA175 & $\begin{array}{l}\text { F:TTGAAGGAACACAATCAGCGAC } \\
\text { R:TGCGCACCAAACTACCATAATC }\end{array}$ & 61 & III & $225-250$ & 3 & 0.740 \\
\hline AA285 & $\begin{array}{l}\text { F:TCGCCTAATCTAGATGAGAATA } \\
\text { R:CTTAACATTTTAGGTCTTGGAG }\end{array}$ & 51 & IV & $250-275$ & 3 & 0.609 \\
\hline AB64 & $\begin{array}{l}\text { F:GCATTCATTGCGGTTGCATTAT } \\
\text { R:GAGTGACAGGTGCCACATTGA }\end{array}$ & 61 & III & $350-400$ & 2 & 0.609 \\
\hline
\end{tabular}

*Tm: melting temperature

\section{RESULTS AND DISCUSSION}

\section{Molecular characterization}

The 14 SSR markers used in this study yielded reproducible polymorphic bands in all of the 132 pea accessions. The primers employed revealed a total of 48 polymorphic alleles. The size of the alleles ranged from $175 \mathrm{bp}$ to $900 \mathrm{bp}$. The number of polymorphic alleles ranged from two to six. The highest number of polymorphic alleles was obtained with primer AD146. The primers AA205 and AB64 generated only two polymorphic alleles. The mean number of alleles per locus was 3.43. In general, the number of alleles revealed by the SSR markers was similar to those in previous reports. Loridon et al. (2005) had reported an average of 3.8 alleles per locus using 309 SSR markers in pea accessions. The PIC values ranged from 0.585 to
0.861 (Tab. 1). The improvements in molecular techniques have enabled us to observe genetic narrowing at the allelic grade. The abundance of allelic variation is of significance with regard to both evolutionary and breeding aspects (van de Wouw et al., 2010). Nisar et al. (2017) reported that the newly developed Pakistani pea lines showed an average of 4.69 alleles per SSR locus. Similarly, an average number of 4.5 alleles per locus was reported in European pea accessions (Cupic et al., 2009). Ahmad et al. (2012), evaluating 35 pea accessions from various sources with 15 SSR loci, found 41 alleles (bands) with an average of 2.73 alleles, i.e. less than the value reported in this study. Similarly, the number of alleles per locus averaged 2.1 in the study by Kumari et al. (2013).

Higher PIC values were calculated in the present study compared with the results of other researchers. 


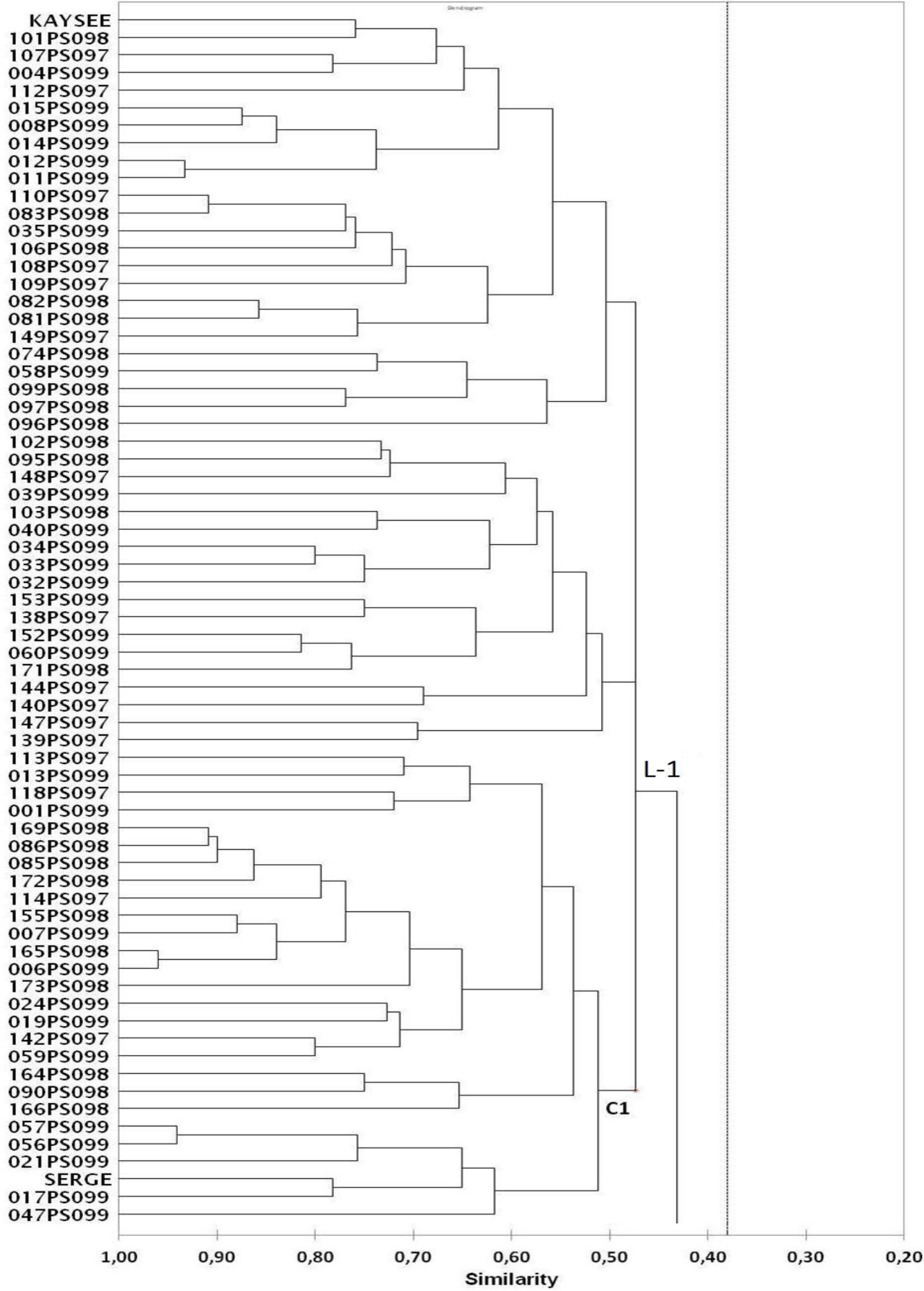

Figure 1A. Dendrogram of pea accessions based on SSR primers. Scale at bottom is Dice's coefficient of similarity (Part I, Linkage-1, Cluster-1)

Ahmad et al. (2012) had obtained much lower PIC values, ranging from 0.055 to 0.660 , when assessing pea accessions with 15 SSR loci. Nisar et al. (2017) calculated the maximum PIC value of 0.630 in 23 pea accessions, while Kumari et al. (2013) obtained the maximum PIC value of 0.657 in 28 accessions. In this study, the high polymorphism rate (average PIC, 0.751; maximum PIC, 0.861) stemmed from the efficiency of the selected SSR primers. The 132 accessions were classified into three linkage groups at genetic distances of $37 \%$ in the cluster analysis (Figs 1A and 1B). Eight clusters were additionally classified into these main groups.

\section{Morphological characterization}

Descriptive statistics for traits demonstrated a substantial variability in the accessions under investigation (Tab. 2). Standard deviations were 


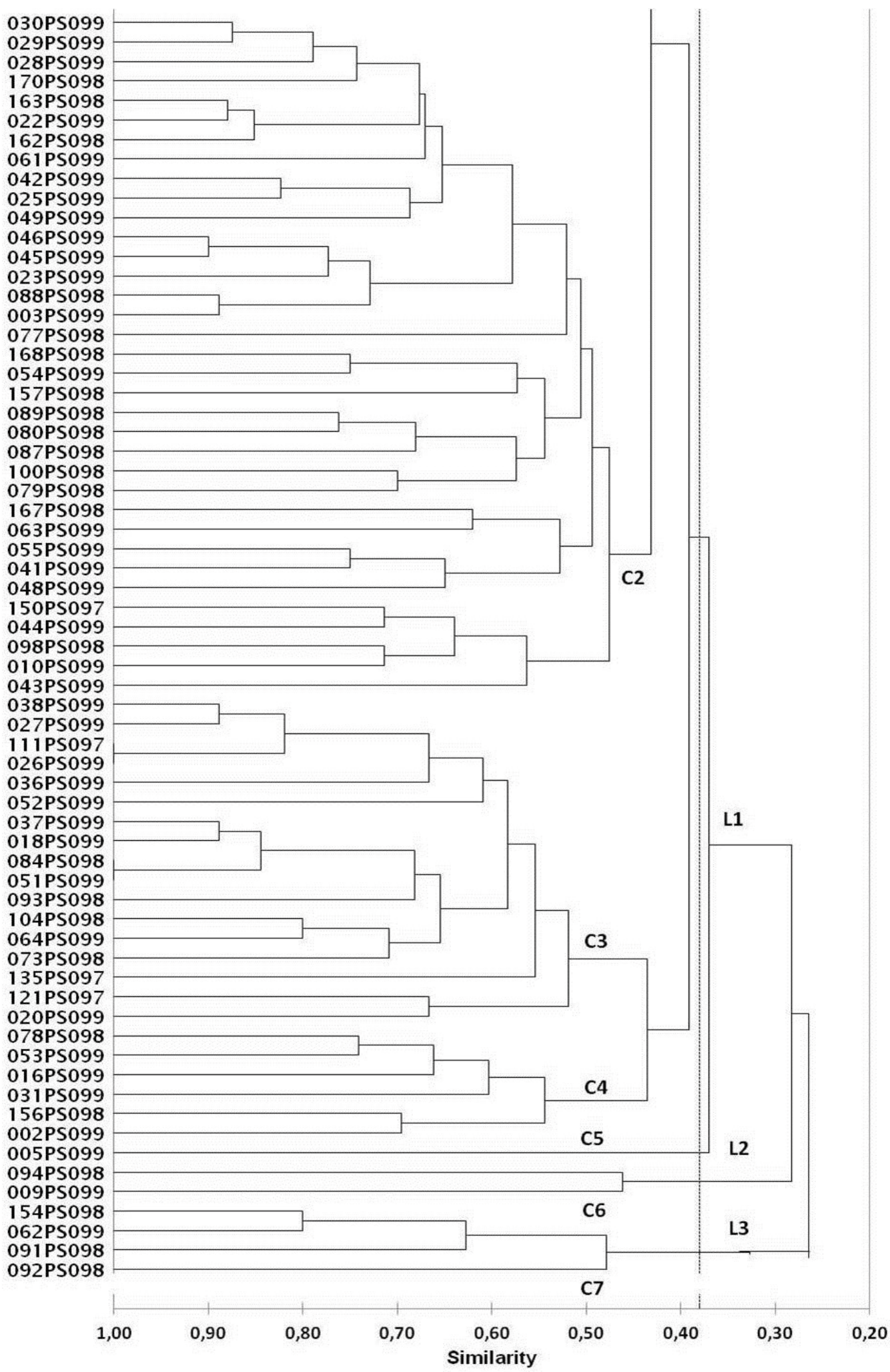

Figure 1B. Dendrogram of pea accessions based on SSR primers. Scale at bottom is Dice's coefficient of similarity (Part II, Linkage-1Cluster 2; Linkage-2 and Linkage-3)

observed at the levels of 19.52 and 7.03, which were relatively high, for the length of the plant (LS17) and the time of flowering (F1), respectively. Cluster analysis performed on the matrix of Euclidean distances generated a dendrogram using the Ward method based on the variations associated with fifty quantitative and qualitative characteristics (Figs $2 \mathrm{~A}$ and $2 \mathrm{~B}$ ). The average dissimilarity index for all the investigated accessions was 9.74. Two main groups were obtained (L1-2) in the cluster analysis. 
Table 2. Morphological traits related to leaf-stem (LS), flower (F), and seed-pod (SP) characteristics, with standard errors and standard deviations (UPOV, 2009)

\begin{tabular}{|c|c|c|c|c|c|c|c|c|}
\hline Trait & SE & SD & Trait & SE & SD & Trait & SE & SD \\
\hline Length of leaflet (LS1) & 0.10 & 1.17 & $\begin{array}{l}\text { Intensity of colour } \\
\text { of foliage (LS19) }\end{array}$ & 0.08 & 0.95 & Shape of seed (SP1) & 0.09 & 1.00 \\
\hline Width of leaflet (LS2) & 0.09 & 1.07 & Stem length (LS20) & 0.12 & 1.36 & $\begin{array}{l}\text { Colour of cotyledon } \\
\text { of seed (SP2) }\end{array}$ & 0.07 & 0.82 \\
\hline Size of leaflet (LS3) & 0.08 & 0.89 & $\begin{array}{l}\text { Number of nodes up to } \\
\text { first fertile node (LS21) }\end{array}$ & 0.10 & 1.18 & Marbling of testa (SP3) & 0.08 & 0.93 \\
\hline Length of stipule (LS4) & 0.10 & 1.16 & $\begin{array}{l}\text { Length from axil to first } \\
\text { leaflet of tender (LS22) }\end{array}$ & 0.10 & 1.18 & $\begin{array}{l}\text { Violet or pink spots on } \\
\text { testa (SP4) }\end{array}$ & 0.06 & 0.65 \\
\hline Width of stipule (LS5) & 0.10 & 1.11 & Time of flowering (F1) & 0.61 & 7.03 & $\begin{array}{l}\text { Hilum colour on seed } \\
\text { (SP5) }\end{array}$ & 0.18 & 2.11 \\
\hline Colour of leaflet (LS6) & 0.06 & 0.71 & $\begin{array}{l}\text { Maximum number } \\
\text { of flowers per node (F2) }\end{array}$ & 0.14 & 1.63 & Colour of testa (SP6) & 0.05 & 0.55 \\
\hline $\begin{array}{l}\text { Intensity of colour of } \\
\text { leaflet (LS7) }\end{array}$ & 0.08 & 0.89 & Colour of wing (F3) & 0.13 & 1.48 & $\begin{array}{l}\text { Wrinkling of seed } \\
\text { cotyledon (SP7) }\end{array}$ & 0.23 & 2.64 \\
\hline $\begin{array}{l}\text { Leaflets (absent or present) } \\
\text { (LS8) }\end{array}$ & 0.04 & 0.43 & $\begin{array}{l}\text { Intensity of colour } \\
\text { of wings (F4) }\end{array}$ & 0.27 & 3.14 & $\begin{array}{l}\text { Type of starch grains } \\
\text { (SP8) }\end{array}$ & 0.03 & 0.33 \\
\hline $\begin{array}{l}\text { Waxiness of upper leaflet } \\
\text { (LS9) }\end{array}$ & 0.05 & 0.56 & $\begin{array}{l}\text { Intensity of colour } \\
\text { of standard (F5) }\end{array}$ & 0.22 & 2.47 & Width of seed (SP9) & 0.13 & 1.43 \\
\hline Dentation of leaflet (LS10) & 0.04 & 0.50 & Colour of standard (F6) & 0.09 & 0.98 & Curvature on pod (SP10) & 0.04 & 0.47 \\
\hline $\begin{array}{l}\text { Degree of dentation of } \\
\text { leaflet (LS11) }\end{array}$ & 0.12 & 1.35 & Width of standard (F7) & 0.12 & 1.43 & $\begin{array}{l}\text { Type of curvature of pod } \\
\text { (SP11) }\end{array}$ & 0.08 & 0.88 \\
\hline Size of stipule (LS12) & 0.02 & 0.19 & $\begin{array}{l}\text { Shape of base of standard } \\
\text { (F8) }\end{array}$ & 0.08 & 0.95 & $\begin{array}{l}\text { Shape of distal part of } \\
\text { pod (SP12) }\end{array}$ & 0.03 & 0.39 \\
\hline Shape of stipule (LS13) & 0.11 & 1.21 & $\begin{array}{l}\text { Undulation of standard } \\
\text { (F9) }\end{array}$ & 0.08 & 0.94 & Colour of pod (SP13) & 0.03 & 0.36 \\
\hline Flecking of stipule (LS14) & 0.10 & 1.10 & Width of upper sepal (F10) & 0.08 & 0.88 & $\begin{array}{l}\text { Intensity of green } \\
\text { colour of pod (SP14) }\end{array}$ & 0.11 & 1.22 \\
\hline $\begin{array}{l}\text { Density of flecking } \\
\text { of stipule (LS15) }\end{array}$ & 0.09 & 0.99 & $\begin{array}{l}\text { Shape of apex of upper } \\
\text { sepal (F11) }\end{array}$ & 0.04 & 0.47 & $\begin{array}{l}\text { Anthocyanin coloration } \\
\text { of parchment (SP15) }\end{array}$ & 0.06 & 0.71 \\
\hline $\begin{array}{l}\text { Anthocyanin coloration } \\
\text { of stem (LS16) }\end{array}$ & 0.09 & 1.01 & $\begin{array}{l}\text { Length of peduncle } \\
\text { (from first flower) (F12) }\end{array}$ & 0.12 & 1.40 & $\begin{array}{l}\text { Anthocyanin coloration } \\
\text { of pod (SP16) }\end{array}$ & 0.03 & 0.31 \\
\hline Length of plant (LS17) & 1.70 & 19.52 & & & & & & \\
\hline Fasciation of stem (LS18) & 0.06 & 0.69 & & & & & & \\
\hline
\end{tabular}

SE: Standard error, SD: Standard deviation

Group-I (L1) consisted of two clusters (C1-2). A relationship was observed between the accessions in these clusters based on days to flower initiation. The first cluster (C1) consisted of 46 accessions and, in general, late-flowering accessions clustered in this group (avg. 63 days). The second cluster consisted of 31 accessions, and the most prominent feature of this cluster was that it included the earliest flowering accessions (avg. 45 days). The commercial cultivars Serge and Kaysee were in cluster C2. The second group (L2) consisted of two clusters. The third cluster (C-3) consisted of only seven accessions. These accessions showed radically different morphological features compared to the others. Finally, the fourth cluster (C4) had 48 accessions.

The first fifteen principal components (PCs) with eigenvalues greater than one accounted for $74.08 \%$ of total variability amongst the 132 pea accessions. The proportion of total variation explained by these principal components of more than $2 / 3$ was used for the next step (Hanci and Gökçe, 2016b). The percentages of cumulative variation explained by each of the seven PCs were $13.88 \%, 25.29 \%, 32.61 \%, 38.05 \%, 43.21 \%$, 47.65\% and 51.545, respectively (Tab. 3). In each principal component, a coefficient equal to or greater than 0.3 was determined as the threshold to define the cut-off limit for the coefficients of the accurate vectors (Raji, 2002). The first principal component (PC1) had a high positive value for the colour of the wings (F3), the intensity of the colour of the wings (F4), and the intensity of the colour of the standard banner (F5). PC1 had a negative value for the colour of the standard (F6). The second principal component had a high positive value for the width 


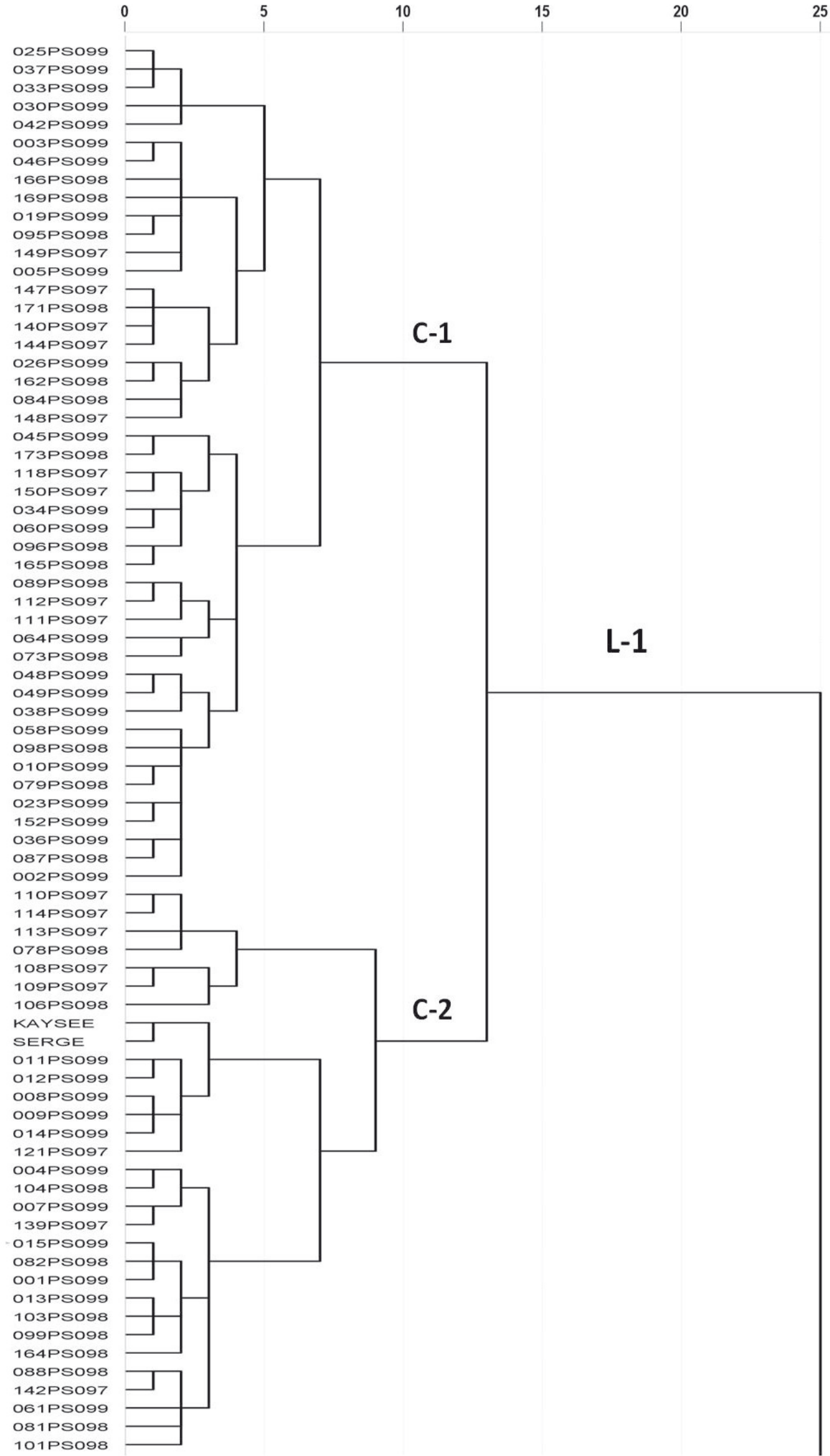

Figure 2A. Dendrogram of pea accessions constructed using UPGMA based on morphological data (Part-I, Linkage-1) 


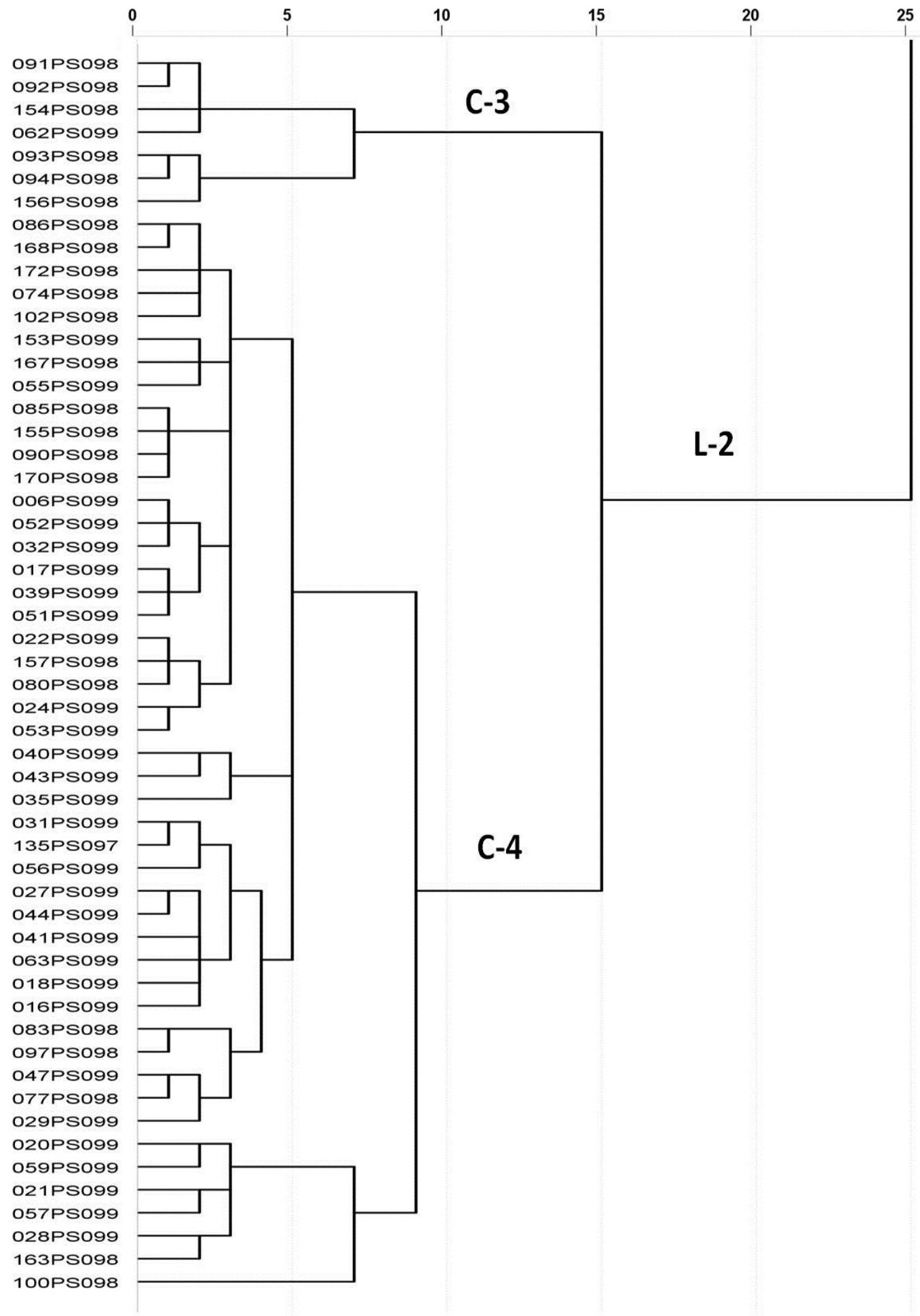

Figure 2B. Dendrogram of pea accessions constructed using UPGMA based on morphological data (Part-II, Linkage-2)

of the leaflet (LS2), the size of the leaflet (LS3), and the width of the stipule (LS5). Having such high positive or negative component values, these traits reveal high genetic diversity. In the study by Smýkal et al. (2008), the PCA of the morphological traits disclosed that $82 \%$ of the total variation was explained by 3 principal components comprising $48.8 \%, 27.0 \%$, and $6.0 \%$, respectively. In the
Albanian pea germplasm, $86.91 \%$ of the variation was explained by the first three PCs (Gixhari et al., 2014). In the same study, the total contribution of quantitative traits included in $\mathrm{PC} 1$ accounted for $58.1 \%$ of $\mathrm{PC} 1$ variance.

Dice's similarity coefficient varied in the range from 0.091 to 0.960 , with an average of 0.439 , showing the genetic distance between Turkish 
Table 3. Eigenvectors of the first seven principal components

\begin{tabular}{|c|c|c|c|c|c|c|c|c|c|c|c|c|c|c|c|}
\hline \multirow{2}{*}{ Trait* } & \multicolumn{7}{|c|}{ Eigenvectors } & \multirow{2}{*}{ Trait } & \multicolumn{7}{|c|}{ Eigenvectors } \\
\hline & PC1 & $\mathrm{PC} 2$ & PC3 & $\mathrm{PC} 4$ & PC5 & PC6 & PC7 & & $\mathrm{PC} 1$ & $\mathrm{PC} 2$ & PC3 & $\mathrm{PC} 4$ & PC5 & PC6 & PC7 \\
\hline LS1 & -0.01 & 0.28 & 0.14 & 0.03 & 0.03 & 0.12 & 0.07 & SP4 & -0.03 & 0.07 & -0.13 & 0.05 & -0.08 & 0.27 & 0.10 \\
\hline LS2 & -0.05 & 0.33 & 0.12 & 0.13 & 0.12 & 0.08 & 0.07 & SP5 & 0.22 & 0.01 & 0.02 & 0.05 & 0.10 & -0.08 & 0.13 \\
\hline LS3 & -0.09 & 0.31 & 0.12 & 0.08 & 0.11 & 0.08 & 0.06 & SP6 & -0.22 & -0.02 & -0.10 & 0.08 & 0.03 & 0.06 & -0.01 \\
\hline LS4 & -0.05 & 0.29 & 0.10 & 0.00 & 0.06 & 0.13 & 0.14 & SP7 & -0.13 & -0.04 & 0.14 & -0.39 & 0.29 & -0.05 & 0.07 \\
\hline LS5 & -0.08 & 0.31 & 0.10 & 0.08 & 0.13 & 0.08 & 0.08 & SP8 & -0.16 & -0.02 & 0.11 & -0.36 & 0.29 & -0.05 & 0.05 \\
\hline LS6 & 0.02 & -0.19 & -0.12 & 0.01 & 0.20 & 0.06 & 0.00 & SP9 & -0.12 & 0.20 & 0.16 & 0.03 & 0.09 & 0.03 & 0.00 \\
\hline LS7 & 0.01 & -0.23 & -0.06 & 0.05 & 0.14 & 0.19 & 0.05 & SP10 & 0.10 & -0.04 & -0.13 & 0.21 & 0.26 & -0.29 & 0.11 \\
\hline LS8 & -0.04 & -0.02 & -0.08 & -0.07 & 0.28 & 0.11 & -0.19 & SP11 & 0.11 & -0.09 & -0.10 & 0.26 & 0.27 & -0.27 & 0.11 \\
\hline LS9 & -0.02 & 0.03 & -0.09 & 0.10 & -0.03 & 0.12 & 0.11 & SP12 & -0.03 & -0.11 & 0.09 & 0.00 & 0.09 & -0.02 & 0.31 \\
\hline LS10 & 0.10 & -0.11 & -0.03 & 0.07 & -0.09 & 0.20 & 0.39 & SP13 & -0.09 & 0.00 & 0.17 & 0.05 & 0.01 & 0.24 & -0.12 \\
\hline LS11 & 0.13 & -0.20 & -0.04 & 0.08 & -0.05 & 0.17 & 0.30 & SP14 & -0.07 & -0.02 & 0.11 & 0.08 & -0.05 & 0.25 & 0.03 \\
\hline LS12 & -0.09 & 0.26 & -0.10 & -0.17 & -0.11 & -0.03 & 0.02 & SP15 & 0.02 & -0.01 & 0.25 & 0.22 & 0.12 & 0.11 & -0.24 \\
\hline LS13 & 0.02 & 0.04 & 0.08 & -0.13 & -0.24 & -0.24 & 0.16 & SP16 & 0.06 & -0.17 & 0.23 & 0.26 & 0.17 & 0.04 & -0.13 \\
\hline LS14 & 0.10 & 0.08 & 0.20 & 0.03 & -0.20 & -0.28 & 0.26 & $\mathrm{~F} 1$ & 0.13 & 0.07 & -0.25 & -0.12 & -0.01 & 0.09 & 0.06 \\
\hline LS15 & 0.06 & 0.11 & 0.17 & 0.01 & -0.05 & -0.24 & 0.22 & $\mathrm{~F} 2$ & -0.06 & 0.10 & -0.02 & -0.11 & -0.02 & 0.04 & 0.14 \\
\hline LS16 & 0.26 & -0.06 & 0.17 & -0.02 & 0.03 & 0.07 & -0.06 & F3 & 0.33 & -0.01 & 0.15 & -0.10 & -0.04 & 0.12 & -0.08 \\
\hline LS17 & 0.17 & 0.13 & -0.10 & 0.16 & 0.02 & -0.10 & -0.04 & F4 & 0.33 & -0.01 & 0.16 & -0.09 & -0.02 & 0.12 & -0.09 \\
\hline LS18 & 0.04 & 0.03 & -0.04 & -0.16 & -0.22 & -0.03 & -0.23 & F5 & 0.32 & 0.05 & 0.15 & -0.11 & -0.02 & 0.08 & -0.05 \\
\hline LS19 & 0.24 & 0.05 & 0.17 & -0.10 & 0.07 & -0.11 & -0.03 & F6 & -0.30 & -0.04 & -0.08 & 0.01 & -0.06 & -0.18 & 0.02 \\
\hline LS20 & 0.00 & 0.21 & -0.12 & 0.13 & 0.11 & -0.09 & -0.22 & F7 & 0.15 & 0.12 & -0.16 & -0.05 & 0.25 & 0.09 & 0.12 \\
\hline LS21 & 0.10 & 0.14 & -0.17 & -0.02 & -0.11 & -0.05 & -0.20 & F8 & -0.07 & -0.06 & 0.11 & 0.18 & 0.13 & 0.03 & 0.12 \\
\hline LS22 & 0.03 & 0.10 & -0.14 & 0.10 & 0.04 & -0.10 & -0.14 & F9 & 0.11 & 0.08 & -0.28 & -0.13 & 0.16 & 0.01 & -0.03 \\
\hline SP1 & -0.02 & -0.10 & 0.11 & -0.36 & 0.22 & -0.02 & 0.07 & F10 & -0.03 & 0.10 & 0.02 & 0.10 & 0.14 & -0.13 & 0.01 \\
\hline SP2 & 0.22 & 0.12 & 0.04 & -0.01 & 0.02 & -0.12 & -0.03 & F11 & -0.12 & -0.10 & 0.26 & 0.11 & -0.16 & -0.08 & -0.07 \\
\hline SP3 & 0.01 & 0.07 & -0.18 & 0.05 & -0.12 & 0.24 & 0.17 & F12 & 0.22 & 0.15 & -0.19 & -0.03 & 0.07 & 0.04 & 0.06 \\
\hline
\end{tabular}

*Explanations: see Table 2

pea accessions. Kumari et al. (2013) had reported narrow diversity (0.11-0.73) among 28 pea cultivars. In the study by Cupic et al. (2009), the estimated genetic distance among pea accessions based on SSR markers ranged from 0.24 to 0.84 . In another study, the RAPD and AFLP markers were compared to determine effectiveness in pea germplasm. At the end of the study, similar ranges of genetic distance coefficients were obtained with RAPD and AFLP markers, 0.80-0.94 and 0.85-0.94, respectively (Simioniuc et al., 2002). However, a much wider range of similarity (0.0-1.0) was determined in 148 Pisum germplasm using protein and PCR-based markers (Baranger et al., 2004).

No relationship was observed between molecular data and morphology according to the genetic similarity results. All the accessions were classified into two linkage groups in accordance with the morphological data. This result was similar to the results of previous studies where 35 pea accessions had been classified into two major clusters and seven sub-clusters (Nisar et al., 2017), and 28 pea lines into three groups (Gixhari et al., 2014).

In the literature, the pea genotypes which flowered after more than 60 days from sowing were grouped within the class of "late varieties" (Solberg et al., 2015). In our study, the flowering time ranged from 43 to 80 days, with an average of 62 days. Eighty seven accessions, in total, were late flowering (60 days or later). Nisar (2008) had reported that days to flower initiation ranged from 45 to 141 days in Pakistani conditions. The number of flowers per node ranged from one to seven. The majority of accessions had fewer than five flowers per node $(77 \%)$. The accessions differed significantly in plant height, averaging $60.3 \mathrm{~cm}$, and it varied between 25 and $120 \mathrm{~cm}$ among all the accessions. Researchers have obtained similar results for maximum plant height, varying between 65.67 and $132 \mathrm{~cm}$ (Ceyhan and Avci, 2015), 51.20 and $111.30 \mathrm{~cm}$ (Georgieva et al., 2016), and 65.67 and $126 \mathrm{~cm}$ (Khan et al., 2013). The largest fresh 
seed diameter was measured in the commercial cultivar Serge and 020PS099 (13 mm), while 41PS099 showed the smallest (4 mm). The results obtained revealed the presence of a great genetic diversity for all characteristics studied, which is in concordance with the findings of Ouafi et al. (2016), Gixhari et al. (2014), and Khan et al. (2013), who analyzed genetic variation in pea germplasm.

\section{CONCLUSIONS}

This study was designed to look into the genetic richness in Turkish pea accessions by analysing morphological characteristics and molecular markers (SSRs). The application of modern molecular markers in pea, such as marker-assisted selection, determination of regions influencing quantitative trait loci (Tar'an et al., 2005), and assessment of variation (Baranger et al., 2004) provide great benefit for breeding programs. The determination of genetic diversity could benefit genetic and genomic analyses and the exploitation of genetic variation in pea breeding (Nisar et al., 2017). Kwon et al. (2012) reported that the range of the genetic distance values (0.0280 to 0.5147$)$ proved that redundancy had, for the most part, been successfully eliminated from the core collection. The morphological traits examined in this research revealed substantial differences between accessions. Clustering of accessions by multivariate techniques may provide breeders with advantages.

The pea is a crop plant of significant importance for Turkey due to its contribution to the advancement of the agricultural sector. The results indicate that the Turkish pea collection preserves a relatively high variability. According to our results, the richness of the Turkish pea genetic resources can be of benefit in cultivar improvement programmes and breeding studies. Members representing certain groups may be recommended for particular breeding programmes.

\section{ACKNOWLEDGEMENT}

The author thanks the Western Regional Plant Introduction Station, (USA), John Innes Centre (JIC, UK), and the Plant Gene Bank of the Aegean Agricultural Research Institute for providing the seeds.

\section{FUNDING}

This work is part of Project No: TAGEM/BBAD/ 16/ A09/P05/05, supported by the General Directorate of Agricultural Research and Policies, the Republic of Turkey.

\section{AUTHOR CONTRIBUTIONS}

All stages of the study were carried out by Fatih Hanci.

\section{CONFLICT OF INTEREST}

Author declare no conflict of interest.

\section{REFERENCES}

Ahmad S., Singh M., Lamb-Palmer N.D., Lefsrud M., Singh J., 2012. Assessment of genetic diversity in 35 Pisum sativum accessions using microsatellite markers. Can. J. Plant Sci. 92, 1075-1081.

Baranger A., Aubert G., Arnau G., Lainé A.L., Deniot G., Potier J., ET AL., 2004. Genetic diversity within Pisum sativum using protein and PCR-based markers. Theor. Appl. Genet. 108, 1309-1321.

Ceyhan E., Avci M.A., 2015. Determination of some agricultural characters of developed pea (Pisum sativum L.) lines. World Academy Sci., Eng Tech. Agricult. Biosys. Eng. 9(12), https://waset.org/ Publication/10003051.

Cuevas H.E., Prom L.K., 2013. Assessment of molecular diversity and population structure of the Ethiopian sorghum [Sorghum bicolor L. Moench] germplasm collection maintained by the USDA-ARS National Plant Germplasm System using SSR markers. Genet. Resour. Crop Ev. 60, 1817-1830.

Cupic T., Tucak M., Popovic S., Bolaric S., Grluusic S., Kozumplik V., 2009. Genetic diversity of pea (Pisum sativum L.) genotypes assessed by pedigree, morphological and molecular data. J. Food Agric. Environ. 7, 343-348.

Garcia-Vallve S., Palau J., Romeu A., 1999. Horizontal gene transfer in glycosyl hydrolases inferred from codon usage in Escherichia coli and Bacillus subtilis. Mol. Biol. Evol. 16, 1125-1134.

Georgieva N., Nikolova I., Kosev V., 2016. Evaluation of genetic divergence and heritability in pea (Pisum sativum L.). J. BioSci. Biotechnol. 5, 61-67.

Gixhari B., Pavelková.M., Ismaili H., Vrapi H., Jaupi A., SmÝKal P., 2014. Genetic diversity of Albanian pea (Pisum sativum L.) landraces assessed by morphological traits and molecular markers. Czech J. Genet. Plant Breed. 50, 177-184.

HANCI F, GöKÇE A.F., 2016a. Molecular characterization of Turkish onion germplasm using SSR markers. Czech J. Genet. Plant Breed. 52, 71-76.

Hanci F., GöKÇE A.F., 2016b. Genetic diversity evaluations in Turkish onion (Allium cepa L.) genotypes: principal component analyses (PCA) for breeding strategies. Acta Hortic. 1143, 227-234.

Hildebrand C.E., Torney D.C., Wagner R.P., 1992. Informativeness of polymorphic DNA markers. 
In: The Human Genome Project. Deciphering the Blueprint of Hederity. N.C. Cooper (Ed.) University Science Books, Mill Valley, CA, USA, 100-102.

Izzah N.K., Lee J., Perumal S., Park J.Y., Ahn K., Fu D., ET AL., 2013. Microsatellite-based analysis of genetic diversity in 91 commercial Brassica oleracea L. cultivars belonging to six varietal groups. Genet. Resour. Crop Evol. 60, 1967-1986.

Khan T.N., Ramzan A., Jillani G., Mehmood T., 2013. Morphological performance of peas (Pisum sativum) genotypes under rainfed conditions of Potowar region. J. Agric. Res. 51, 51-60.

Kumari P., Basal N., Singh A.K., Rai V.P., Srivastava C.P., Singh P.K., 2013. Genetic diversity studies in pea (Pisum sativum L.) using simple sequence repeat markers. Genet. Mol. Res. 12, 3540-3550.

Kwon S.J., . Brown A.F., Hu J., Mcgee R., Watt C., Kisha T., ET AL., 2012. Genetic diversity, population structure and genome-wide marker-trait association analysis emphasizing seed nutrients of the USDA pea (Pisum sativum L.) core collection. Genes Genom. 34, 305-320.

Lewis G.P., Schrire B., Mackinder B., Lock M., 2005. Legumes of the World. Royal Botanic Gardens, Kew, UK.

Loridon K., Mcphee K., Morin J., Dubreuil P., PiletNayel M.L., Aubert G., ET AL., 2005. Microsatellite marker polymorphism and mapping in pea (Pisum sativum L.). Theor. Appl. Genet. 111, 1022-1031.

Nasiri J., Haghnazari A., Saba J., 2009. Genetic diversity among varieties and wild species accessions of pea (Pisum sativum L.) based on SSR markers. Afr. J. Biotechnol. 8, 3405-3417.

Nisar M., 2008. Genetic diversity in pea (Pisum sativum L.) for morphological characteristics and molecular markers. Doctoral thesis, Univ. Quaid-I Azam University, Islamabad, Pakistan.

Nisar M., Khan A., Wadood S.F., Shah A.A., Hanci F., 2017. Molecular characterization of edible pea through EST-SSR markers. Turk. J. Bot. 41, 338-346.

Ouafi L., Alane F., Rahal-Bouziane H., AbDelguerfi A., 2016. Agro-morphological diversity within field pea (Pisum sativum L.) genotypes. Afr. J. Agric. Res. 11(40), 4039-4047.

Raji A.A., 2002. Assessment of genetic diversity and heterotic relationships in African improved and local cassava (Manihot esculenta Crantz) germplasm. Doctoral thesis, Univ. Ibadan, Nigeria.

RaO N.K., 2004. Plant genetic resources: advancing conservation and use through biotechnology. Afr. J. Biotechnol. 3, 136-145.
Simioniuc D., Uptmoor R., Friedt W., Ordon F., Swiecicki W., 2002. Genetic diversity and relationships among pea cultivars revealed by RAPDs and AFLPs. Plant Breed. 121, 429-435.

SmÝkal P., Hybl M., Corander J., Jarkovsky J., Flavell A.J., Griga M., 2008. Genetic diversity and population structure of pea (Pisum sativum L.) varieties derived from combined retrotransposon, microsatellite and morphological marker analysis. Theor. Appl. Genet. 117(3), 413-424.

Smýkal P., Coyne C., Redden R., Maxted N., 2013. Peas. In: Genetic and Genomic Resources of Grain Legume Improvement. M. Singh and H. Upadhyaya (Eds), Elsevier, Netherlands, 41-80.

Solberg S.O., Brantestam A.K., Olsson K., Leino M.W., Weibull J., Yndgaard F., 2015. Diversity in local cultivars of Pisum sativum collected from home gardens in Sweden. Biochem. Syst. Ecol. 62, 194-203.

Tar'an B., Zhang C., Warkentin T., Tullu A., VANDENBERG A., 2005. Genetic diversity among varieties and wild species accessions of pea (Pisum sativum L.) based on molecular markers, and morphological and physiological characters. Genome 48, 257-272.

Tatikonda L., Wani S.P., Kannan S., Beerelli N., Sreedevi T.K., Hoisington D.A., et AL., 2009. AFLP-based molecular characterization of an elite germplasm collection of Jatropha curcas L., a biofuel plant. Plant Sci. 176, 505-513.

UPOV, 2009. International Convention for the Protection of New Varieties of Plants, UPOV, 22 October, Geneva.

van de Wouw M., van Hintum T., KiK C., van Treuren R., Visser B., 2010. Genetic diversity trends in twentieth century crop cultivars: a meta analysis. Theor. Appl. Genet. 120, 1241-1252.

Yirga H., Mohammed H., Abate B., 2013. Characterization and preliminary evaluation of dekoko (Pisum sativum var. abyssinicum) accessions using quantitative traits in Southern Tigray, Ethiopia. IJTEEE 1(4), 86-89.

ZIEGEL E., 2006. Technometrics. In: Encyclopedia of Environmetrics 1-4. A.H. El Shaarawi and W.W. Piegorsch (Eds), John Wiley \& Sons, 44, 408409.

Received July 26, 2018; accepted October 3, 2018 


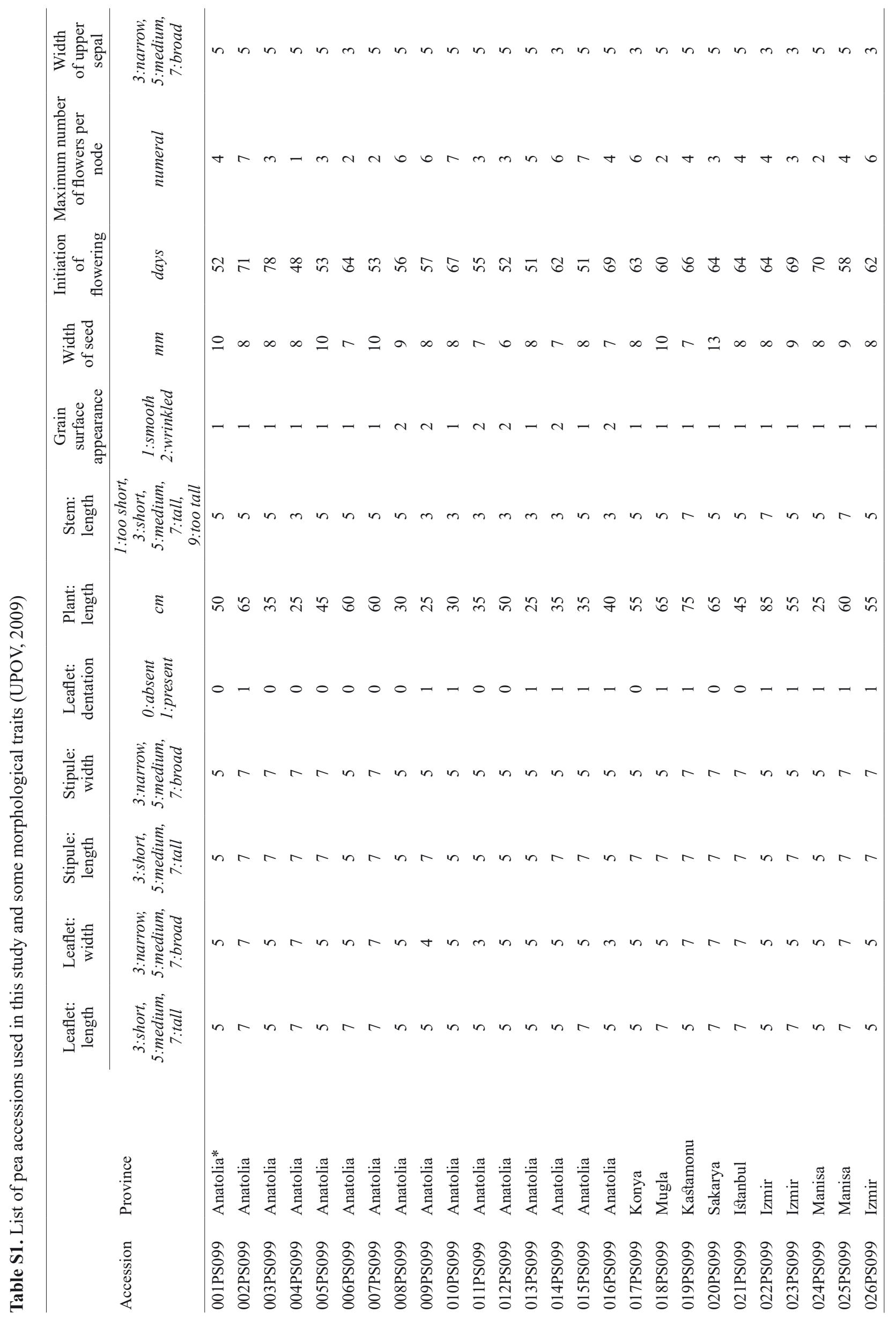




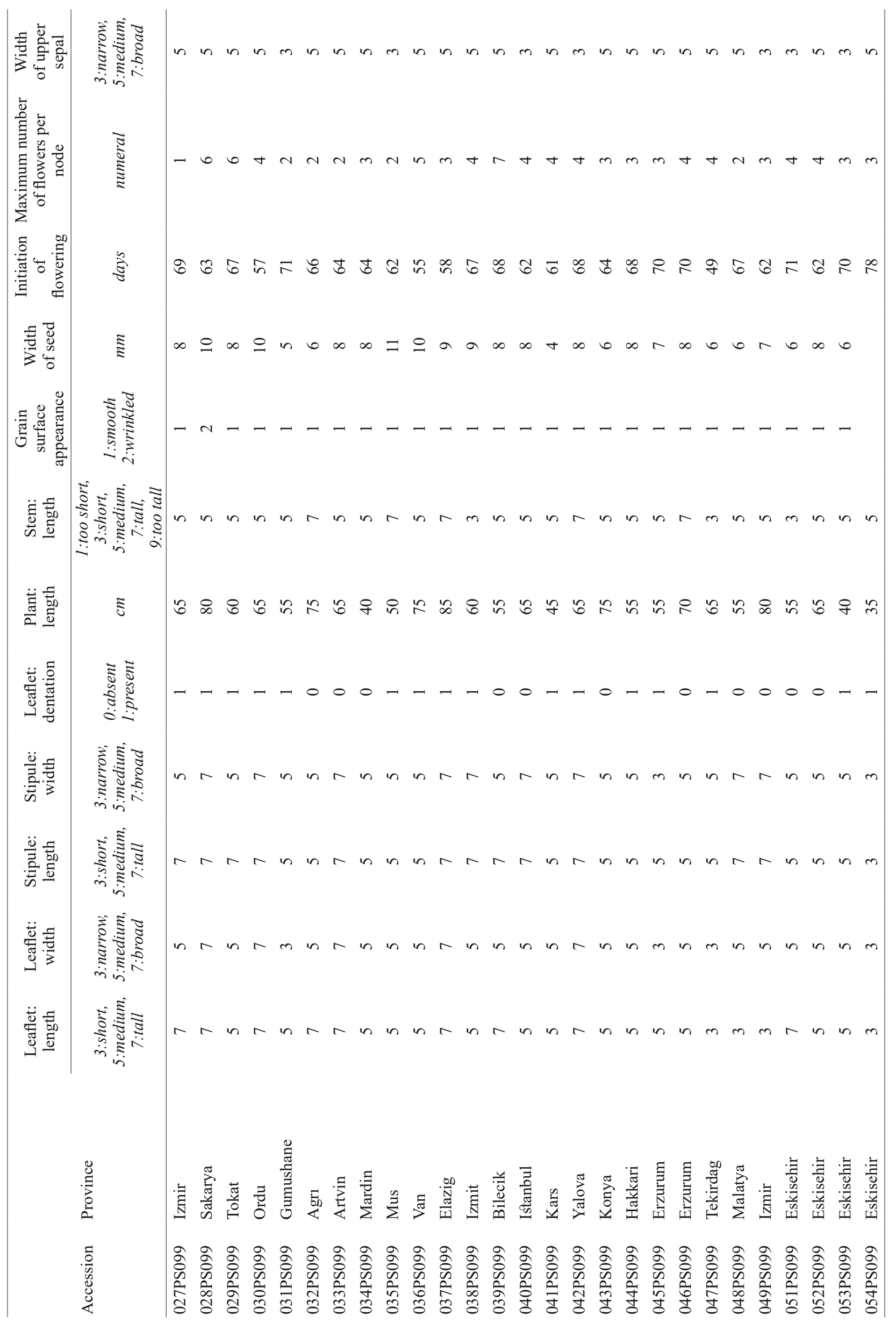




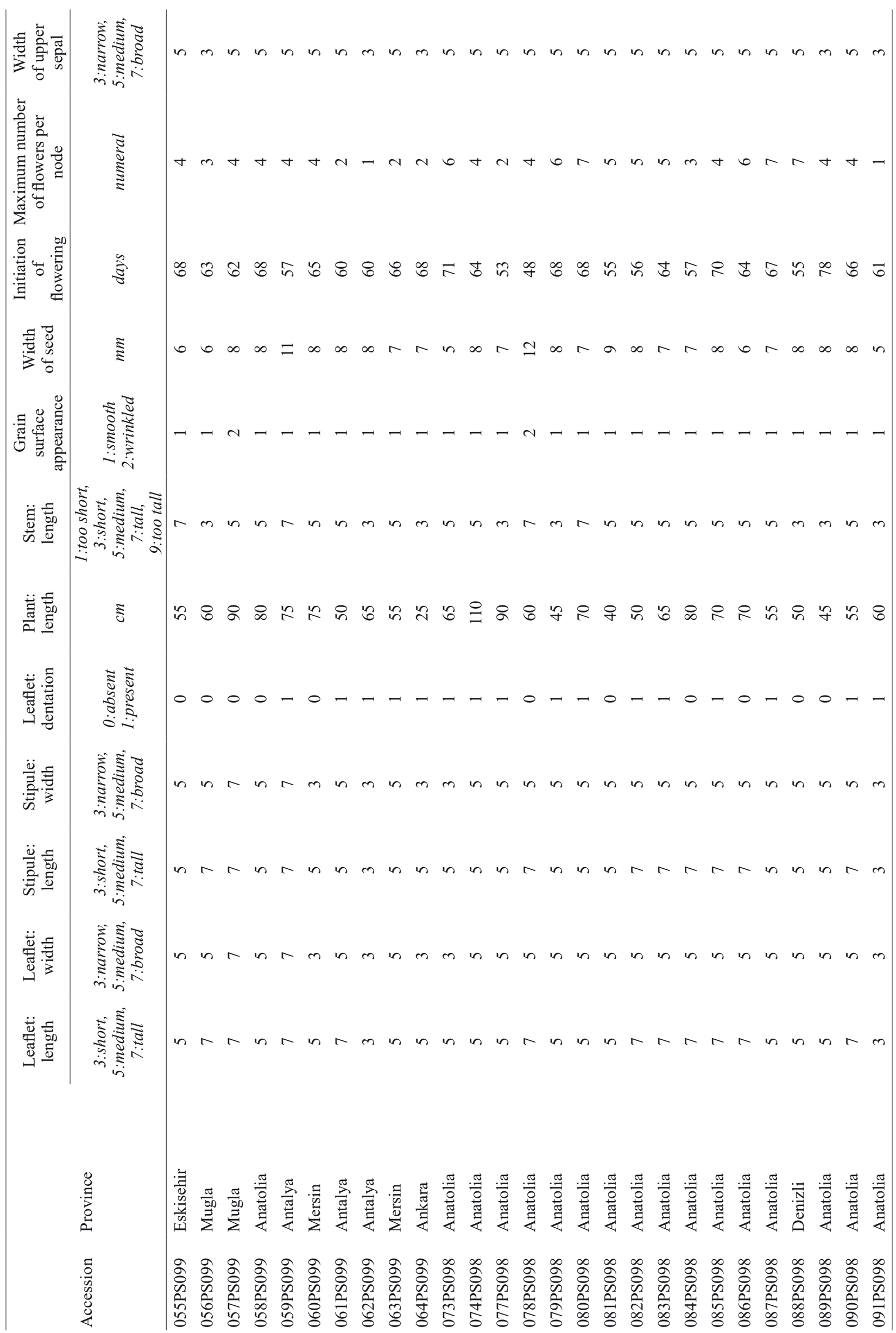




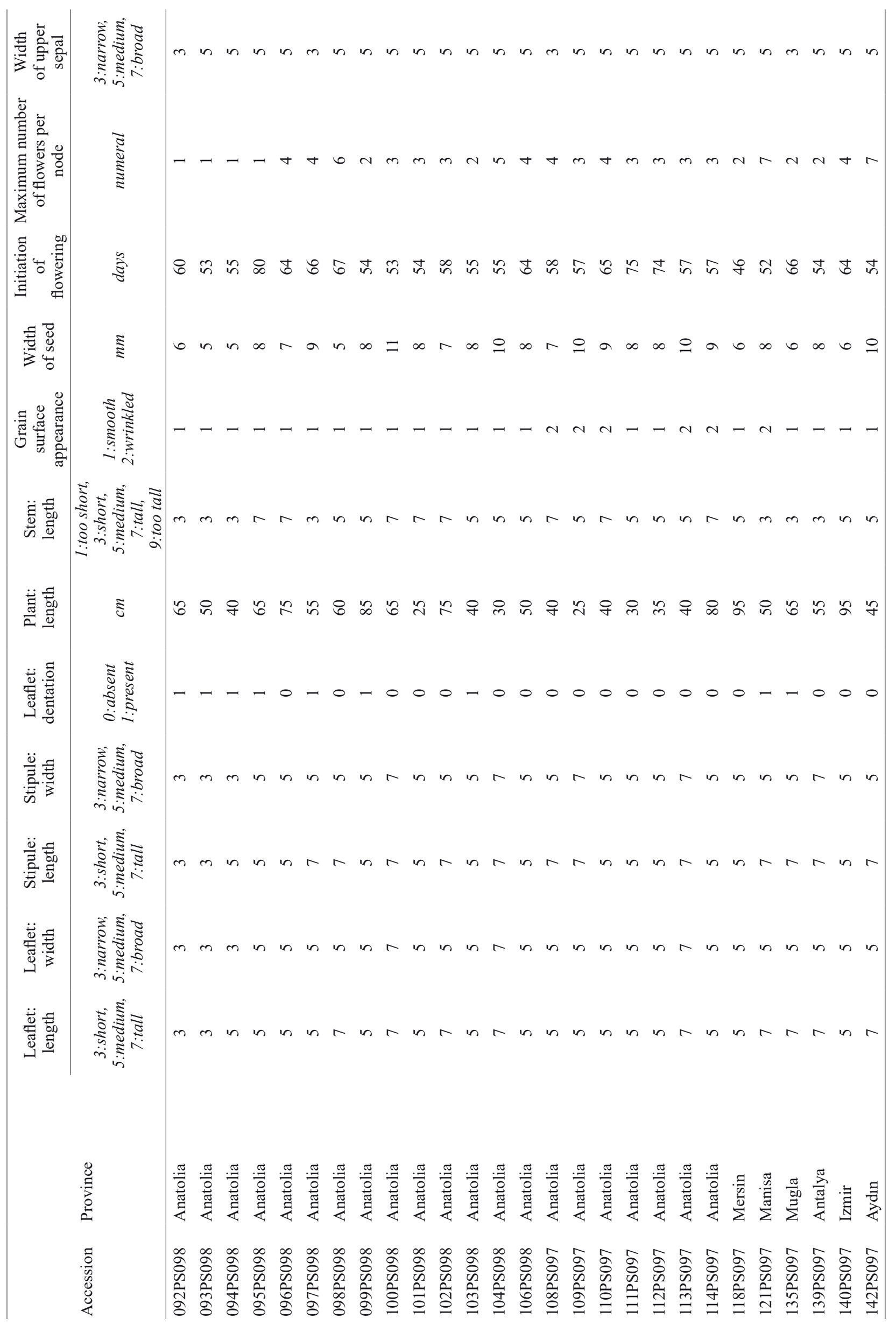




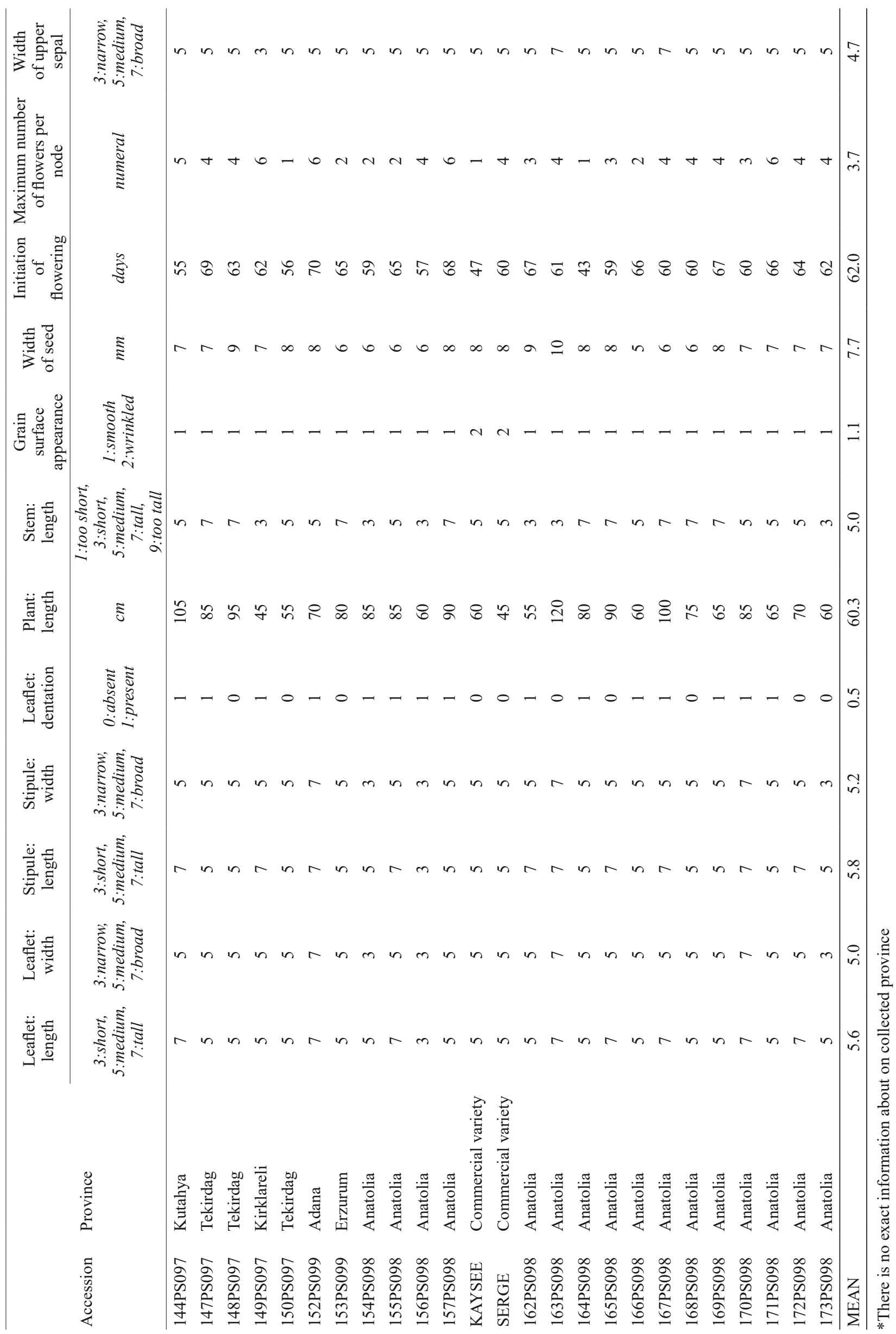

